Jurnal Akuntansi dan Manajemen

Vol.11, No. 2, 2016, Hal.26-42

\title{
Implementasi Akuntabilitas Pada Organisasi Pengelola Zakat (Studi Kasus : Baznas Kabupaten Agam)
}

\author{
Bella Kurnia Putri1), Wiwik Andriani'2), Rasyidah Mustika ${ }^{3)}$ \\ Jurusan Akuntansi, Politeknik Negeri Padang
}

Email: 19 bella.kurnia@gmail.com²) wi_andriani@yahoo.com ${ }^{3)}$ titik.mustika@gmail.com

\begin{abstract}
Zakat is an alternative that can be utilized in poverty reduction. Zakat is expected to minimize the income gap between the rich and the poor. Therefore, zakat management organizations are required to become accountable institutions. This is because funds managed by the zakat management organization are people's funds. This study aims to determine the implementation of accountability in National Zakat Agency (NZA) Agam Regency. The accountability principle used is the principle stated by the Humanitarian Forum Indonesia (HFI) and the Public Interest Research Advocacy Center (PIRAC). Data is collected through interviews, document review and observation. Analysis of the data used is thematic analysis. The results showed that NZA of Agam Regency had implemented a good management of testes. However, the application of the principle of accountability has not been maximized so that it still needs to be improved. It is expected that NZA of Agam Regency can maximize the application of the principle of accountability in the future.
\end{abstract}

Keywords: accountability, accountability principles, zakat management organizations

\begin{abstract}
ABSTRAK
Zakat merupakan alternatif yang dapat didayagunakan dalam penanggulangan kemiskinan. Zakat diharapkan bisa meminimalisir kesenjangan pendapatan antara si kaya dan si miskin. Oleh karena itu, organisasi pengelola zakat dituntut menjadi accountable institution. Hal ini karena dana yang dikelola oleh organisasi pengelola zakat merupakan dana umat. Penelitian ini bertujuan untuk mengetahui implementasi akuntabilitas pada BAZNAS Kabupaten Agam. Prinsip akuntabilitas yang digunakan adalah prinsip yang dikemukakan oleh Humanitarian Forum Indonesia (HFI) dan Public Interest Research Advocacy Center (PIRAC). Data dikumpulkan melalui wawancara, dokumen review dan observasi. Analisis data yang digunakan adalah analisis tematik. Hasil penelitian menunjukkan bahwa BAZNAS Kabupaten Agam telah mengimplementasikan akuntabilitas pengelolaan zakar dengan cukup baik. Hanya saja, penerapan prinsip akuntabilitas ini belum maksimal sehingga masih harus ditingkatkan lagi. Diharapkan BAZNAS Kabupaten Agam dapat memaksimalkan penerapan prinsip akuntabilitas ini kedepannya.
\end{abstract}

Kata kunci: akuntabilitas, prinsip akuntabilitas, organisasi pengelola zakat

\section{PENDAHULUAN}

Zakat merupakan ibadah yang memiliki posisi yang sangat penting, strategis dan menentukan dari sisi pembangunan kesejahteraan umat. Zakat termasuk rukun keempat dari rukun Islam. Zakat diharapkan dapat meminimalisir kesenjangan pendapatan antara si kaya dan si miskin. Melalui zakat, kehidupan fakir, miskin dan orang- orang menderita lainnya akan terperhatikan dengan baik. Potensi dana umat Islam yang terkumpul dari zakat merupakan solusi alternatif yang dapat didayagunakan bagi upaya penanggulangan kemiskinan di Indonesia dan pemberdayaan ekonomi umat, yang tidak dapat terpecahkan dan teratasi hanya dengan dana APBN yang berasal dari penerimaan pajak maupun hutang luar negeri. Potensi zakat di masyarakat memang cukup besar, jika tidak dikelola dengan baik akan menjadi hal yang merugikan. Keberadaan lembaga amil zakat, baik pemerintah atau independen, seharusnya bisa menjadi garda terdepan dalam inisiator pemberdayaan masyarakat dengan berbekal funding yang telah dikumpulkan. 
Dalam UU No. 23 Tahun 2011 tentang Pengelolaan Zakat disebutkan bahwa pengelolaan zakat berasaskan syari'at Islam, amanah, kemanfaatan, keadilan, kepastian hukum, terintegrasi dan akuntabilitas. Poin terakhir dari pasal tersebut merupakan hal yang tidak kalah penting dibanding hal lainnya, mengingat aktivitas di organisasi pengelola zakat berhubungan dengan keuangan (Asahi, 2014). Akuntabilitas menjadi urgent bagi Organisasi Pengelola Zakat (OPZ) untuk menumbuhkan kepercayaan masyarakat dalam penyaluran zakatnya. Akuntabilitas juga tersirat dalam Al-Qur'an surat Al Baqarah : 282, yang mewajibkan pencatatan dari setiap aktivitas transaksi (Adlan dalam Endahwati, 2014). Pencatatan transaksi akan memberikan informasi dan akuntabilitas (kekuatan untuk dipertanggungjawabkan) terhadap kondisi riil yang ada kepada publik sebagai objek, pihak yang juga punya hak untuk mempertanyakannya.

Penelitian Endahwati (2014) untuk memahami secara mendalam bagaimana pengelola BAZ memaknai akuntabilitas dalam pengelolaan zakat, infaq, dan shadaqah (ZIS). Penelitian ini menggunakan metode kualitatif deskriptif dengan pendekatan studi kasus (case study). Ia menemukan bahwa akuntabilitas pengelolaan ZIS pada BAZ Kab. Lumajang didasarkan pada akuntabilitas vertikal dan horizontal. Prinsip yang ditekankan dalam akuntabilitas vertikal adalah prinsip amanah. Sedangkan prinsip yang ditekankan dalam akuntabilitas horizontal adalah prinsip profesional dan transparan. Penelitian Asahi (2014) tentang memahami akuntabilitas pada BAZNAS Kota Padang menggunakan mekanisme akuntabilitas yaitu laporan dan pelaporan keuangan, penilaian kinerja, partisipasi, selfregulation, dan audit sosial. Penelitian menggunakan metode kualitatif. Menyimpulkan bahwa akuntabilitas untuk BAZNAS cenderung dilakukan untuk memenuhi kebutuhan informasi bagi pihak eksternal yaitu mitra, pemerintah maupun masyarakat.

Akuntabilitas merupakan kewajiban setiap lembaga pengelola bantuan kemanusiaan baik pihak pemerintah maupun institusi lainnya, seperti Lembaga Swadaya Masyarakat (LSM), media masa, lembaga pendidikan, perusahaan dan organisasi keagamaan. Sebagian organisasi pengelola bantuan kemanusiaan memahami bahwa akuntabilitas sebatas pada pemberian laporan yang telah diaudit oleh akuntan publik. Padahal, akuntabilitas tidak hanya mengacu pada laporan, hukum dan kebijakan nasional tapi juga pada aspek-aspek seperti keterlibatan penerima manfaat, kecepatan pendistribusian, ketepatan menentukan penerima manfaat maupun pendayagunaan bantuan serta bagaimana organisasi tersebut mampu merespon permasalahan baru yang muncul berkaitan dengan pengelolaan bantuan yang diberikan. Artinya akuntabilitas adalah bentuk pertanggungjawaban yang dilakukan tidak hanya kepada lembaga donor/donatur tetapi juga kepada masyarakat umum dan penerima manfaat.

Menurut Humanitarian Forum Indonesia (HFI) dan Public Interest Research Advocacy Center (PIRAC), penerapan akuntabilitas yang baik oleh lembaga pengelola bantuan kemanusiaan termasuk di dalamnya yaitu lembaga pengelola zakat, infak dan shadaqah (ZIS) harus berdasarkan prinsip-prinsip akuntabilitas. Prinsip-prinsip akuntabilitas yang dirumuskan oleh PIRAC diantaranya independensi, komitmen organisasi, kompetensi, non-diskriminasi, partisipasi, transparansi, koordinasi, pembelajaran dan perbaikan, kemitraan, non-proselitis, mekanisme umpan balik, kemandirian dan keberpihakan terhadap kelompok yang rentan. Prinsip-prinsip tersebut dapat dijadikan sebagai self-assessment bagi lembaga pengelola zakat yang hasilnya bisa dipakai menjadi dasar untuk peningkatan kapasitas lembaga tersebut. 
Selain itu, prinsip-prinsip tersebut juga bisa digunakan sebagai upaya memfasilitasi lembaga dalam menilai akuntabilitas kinerjanya masing-masing.

Salah satu organisasi zakat yang tergolong cepat dibentuk melalui campur tangan pemerintah setempat adalah Badan Amil Zakat Nasional Kabupaten Agam yang didirikan tahun 2002. Sebagai lembaga yang telah lama didirikan, tentu saja telah banyak masyarakat yang terbantu dengan adanya lembaga ini. Oleh karena itu, penulis tertarik untuk melakukan penelitian pada BAZNAS Kab. Agam terkait akuntabilitas yang ada pada organisasi ini. Penulis memilih prinsip yang dikemukakan oleh PIRAC dan HFI mengingat BAZNAS Kab. Agam merupakan salah satu dari lembaga pengelola bantuan kemanusiaan seperti yang telah dijabarkan sebelumnya.

\section{TINJAUAN PUSTAKA DAN PERUMUSAN HIPOTESIS Tinjauan Pustaka Akuntabilitas}

Akuntabilitas merupakan suatu cara pertanggungjawaban manajemen atau penerima amanah kepada pemberi amanah atas pengelolaan sumber-sumber daya yang dipercayakan kepadanya baik secara vertikal maupun secara horizontal (Benveniste dalam Endahwati, 2014). Akuntabilitas diartikan sebagai kewajibankewajiban dari individu-individu atau penguasa yang dipercayakan untuk mengelola sumber-sumber daya publik dan yang bersangkutan dengannya untuk dapat menjawab hal-hal yang menyangkut pertanggungjawabannya. Akuntabilitas terkait erat dengan instrumen untuk kegiatan kontrol terutama dalam hal pencapaian hasil pada pelayanan publik dan menyampaikannya secara transparan kepada masyarakat.

Akuntabilitas sangat penting bagi organisasi amal dan sosial (seperti charity, zakat dan wakaf) karena organisasi tersebut melibatkan kepentingan banyak stakeholder sehingga pengelola harus menunjukkan bahwa mereka adalah pihak yang bisa dipercaya dan capable dalam menjalankan tugasnya. Menurut Cordery dan Morley (dalam Ihsan dan Gustina, 2008), akuntabilitas yang harus dipenuhi oleh sebuah organisasi amal terbagi atas beberapa macam, yaitu: (1) Akuntabilitas finansial, bertujuan untuk meyakinkan bahwa uang/harta yang dibawah tanggungjawabnya digunakan untuk tujuan yang tepat. (2) Akuntabilitas proses, bertujuan untuk meyakinkan bahwa penggunaan harta sesuai dengan prosedur yang benar. (3) Akuntabilitas program, bertujuan untuk meyakinkan bahwa kegiatan yang dilakukan organisasi efektif dan sejalan dengan tujuan pendiriannya. Dan (4) akuntabilitas priotitas, bertujuan untuk memenuhi kebutuhan pihak yang bekepentingan dengan organisasi secara efektif.

Menurut Humanitarian Forum Indonesia (HFI) dan Public Interest Research Advocacy Center (PIRAC), prinsip-prinsip akuntabilitas yang harus diterapkan lembaga pengelola bantuan kemanusiaan seperti lembaga pengelola zakat, infak dan shadaqah (ZIS) diantaranya independensi, komitmen organisasi, kompetensi, nondiskriminasi, partisipasi, transparansi, koordinasi, pembelajaran dan perbaikan, kemitraan, non-proselitis, mekanisme umpan balik, kemandirian dan keberpihakan terhadap kelompok yang rentan.

\section{Zakat}

Di dalam Pernyataan Standar Akuntansi Keuangan Nomor 109, zakat diartikan sebagai harta yang wajib dikeluarkan oleh muzakki sesuai dengan ketentuan syariah 
untuk diberikan kepada yang berhak menerimanya (mustahik). Zakat merupakan rukun Islam ke-empat yang dapat dijadikan sebagai sumber pendapatan untuk membantu menanggulangi kemiskinan. Perintah zakat terdapat dalam beberapa surat di dalam al-qur'an, yaitu: Q.S. Al-Baqarah : 43, Q.S. At-Taubah : 103, dan Q.S. Adz-Dzariyat :19. Perintah zakat menjadi wajib bagi yang memenuhi syarat wajib zakat, yaitu: islam, merdeka, baligh, memiliki harta yang mencapai nishap, milik penuh, dan memenuhi haul (Mukti, 2015). Berdasarkan jenisnya, zakat terdiri atas: (1) zakat fitrah adalah zakat yang diwajibkan kepada umat muslim pada bulan Ramadhan, tepatnya pada saat matahari terbenam di akhir bulan Ramadhan dan lebih utama dibayarkan sebelum shalat Idul Fitri. Syarat wajib bagi mereka yang memiliki kelebihan makanan pokok bagi dirinya dan tanggungannya pada saat hari raya. Zakat ini tidak mengenal nisab dan dibayar sebesar satu sha' (setara dengan 3,5 liter atau 2,5 kg makanan pokok masyarakat. (2) Zakat harta adalah zakat yang dibayarkan kapan saja asalkan objek zakat telah memenuhi syarat, mencakup hasil perniagaan, pertanian, pertambangan, hasil laut, hasil ternak, harta temuan, emas, dan perak, serta hasil kerja (profesi) yang memiliki perhitungan sendiri-sendiri (Nurhayati dalam Asahi, 2014).

Golongan yang berhak menerima zakat berdasarkan Q.S. At-Taubah : 60 yaitu : fakir, miskin, amil zakat, muallaf, riqap (budak yang tidak memiliki harta dan ingin merdeka), gharimin (orang yang berutang tidak untuk bermaksiat kepada Allah SWT, dan tidak mampu membayar hutang tersebut), fisabilillah (perjuangan untuk menyebarluaskan agama islam), dan ibnu sabil (orang yang sedang dalam perantauan).

Menurut Sartika (dalam Putri, 2015) tujuan zakat yaitu : (1) mengangkat derajat fakir-miskin dan membantunya keluar dari kesulitan hidup serta penderitaan. (2) Membantu memecahkan permasalahan yang dihadapi para Mustahiq. (3) Membentangkan dan membina tali persaudaraan sesama umat muslim dan manusia pada umumnya. (4) Menghilangkan sifat kikir pemilik harta. (5) Membersihkan sifat iri dan dengki (kecemburuan sosial) dari hati orang-orang miskin. (6) Menjembatani jurang pemisah antara yang kaya dengan yang miskin dalam suatu masyarakat. (7) Mengembangkan rasa tanggung jawab sosial pada diri seseorang terutama bagi mereka yang mempunyai harta. (8) Mendidik manusia untuk disiplin menunaikan kewajiban dan menyerahkan hak orang lain yang ada padanya.

Sedangkan manfaat yang diperoleh dari zakat menurut Rahman (dalam Putri, 2015) adalah: (1) Memperbaiki kedudukan masyarakat dari segi moral dan material karena melalui pendistribusian zakat, maka setiap anggota masyarakat akan menjadi satu sehingga persaudaraan antar muslim semakin kuat. (2) Membersihkan jiwa dari sifat kikir dan bakhil. (3) Dapat menjadi benteng keamanan dalam sistem ekonomi Islam sekaligus menjadi stabilitator dalam kehidupan sosial. (4) Merupakan penyebab turunnya rahmat Allah Subhanahu wa Ta'ala.

Organisasi pengelola zakat (OPZ) adalah sebuah institusi yang bertugas dalam pengelolaan zakat, infaq, dan shadaqah, baik yang dibentuk oleh pemerintah seperti BAZ, maupun yang dibentuk oleh masyarakat dan dilindungi oleh pemerintah seperti LAZ (Khan dalam Wahab, 2011). Lembaga zakat merupakan sebuah lembaga keuangan non-profit yang memiliki beberapa dampak langsung pada ekonomi Islam. Undang-undang Nomor 23 Tahun 2011 mendefenisikan pengelolaan zakat adalah kegiatan perencanaan, pelaksanaan dan pengorganisasian dalam pengumpulan, pendistribusian dan pendayagunaan zakat. Berdasarkan peraturan perundang- 
undangan, di Indonesia terdapat dua jenis organisasi pengelola zakat, yaitu Badan Amil Zakat (BAZ) dan Lembaga Amil Zakat (LAZ). Badan Amil Zakat adalah organisasi pengelola zakat yang dibentuk oleh pemerintah sedangkan Lembaga Amil Zakat (LAZ) adalah lembaga yang dibentuk oleh masyarakat yang bergerak dibidang dakwah, pendidikan, sosial dan kemaslahatan umat yang bertugas mengumpulkan, mendistribusikan dan mendayagunakan zakat (Putri, 2015).

Berdasarkan UU No. 23 Tahun 2011 tentang Pengelolaan Zakat, tujuan dari pengelolaan zakat adalah untuk meningkatkan efektivitas dan efisiensi pelayanan dalam pengelolaan zakat dan meningkatkan manfaat zakat untuk mewujudkan kesejahteraan masyarakat dan penanggulangan kemiskinan. Sedangkan asas-asas organisasi pengelola zakat adalah syariat Islam, amanah, kemanfaatan, keadilan, kepastian hukum, terintegrasi dan akuntabilitas.

Di Indonesia terdapat dua lembaga OPZ yang bersifat yayasan namun karakteristiknya berbeda, yaitu lembaga nirlaba dan lembaga for profit. Lembaga nirlaba didirikan benar-benar bukan untuk mencari laba sedikit pun. Produk lembaga nirlaba adalah nilai dan moral sedangkan produk perusahaan adalah barang dan jasa. Sumber dana lembaga nirlaba adalah donasi masyarakat dan digunakan sepenuhnya untuk kegiatan operasional untuk mencapai visi dan misi lembaga. Melihat tugas dan fungsi OPZ, jelaslah bahwa OPZ adalah salah satu dari sekian banyak lembaga nirlaba. Oleh karena itu, OPZ memiliki karakteristik yang sama dengan karakteristik lembaga nirlaba lainnya, yaitu : (1) Sumber daya, baik berupa dana maupun barang berasal dari para donatur dimana donatur tersebut mempercayakan donasi mereka kepada OPZ dengan harapan bisa memperoleh hasil yang mereka harapkan. (2) Menghasilkan berbagai jasa dalam bentuk pelayanan masyarakat dan tidak mencari laba dari pelayan tersebut. (3) Kepemilikan OPZ tidak sama dengan organisasi bisnis. OPZ bukanlah milik pribadi atau kelompok, melainkan milik umat karena sumber dayanya berasal dari masyarakat. Jika OPZ dilikuidasi, maka kekayaan lembaga tidak boleh dibagikan kepada para pendiri.

\section{Penelitian Terdahulu}

Penelitian Nikmatuniayah (2012) untuk mengetahui bagaimana akuntabilitas laporan keuangan yang dilaksanakan oleh BAZIS Yayasan Daruttaqwa Semarang. Dengan menggunakan metode kualitatif menunjukkan bahwa akuntabilitas laporan keuangan yang dilaksanakan oleh BAZIS Yayasan Daruttaqwa Semarang belum didukung dengan sistem akuntansi dan pelaporan yang memadai untuk publik. Khaerany et.al (2013) meneliti untuk menganalisis pelaksanaan akuntabilitas dan transparansi Dompet Dhuafa Sulawesi Selatan dan pengaruhnya terhadap kualitas Dompet Dhuafa Sulawesi Selatan. Dengan menggunakan metode kuantitatif diperoleh hasil bahwa dalam pandangan muzakki, Dompet Dhuafa Sulawesi Selatan telah melaksanakan prinsip akuntabilitas dan transparansi dengan baik serta memiliki kualitas yang baik.

Selain itu, Asahi (2014) melakukan penelitian dengan tujuan untuk mengetahui akuntabilitas yang terdapat pada BAZNAS Kota Padang dan PKPU Cabang Padang menggunakan adalah metode kualitatif. Hasil penelitian menunjukkan bahwa BAZNAS dan PKPU sama-sama cenderung pada penunjukan upward accountability dan akuntabilitas eksternal. Pertanggungjawabannya lebih diprioritaskan pada kepuasan tingkat atas, baik itu pemerintah maupun donatur. Disimpulkan bahwa PKPU lebih independen dalam mengatur dirinya tanpa harus menunggu peraturan 
pemerintah terlebih dahulu. Hal ini indentik dengan karakter PKPU sebagai lembaga kemanusiaan bentukan masyarakat dan tidak terikat pada pemerintah.

Endahwati (2014) meneliti untuk memahami secara mendalam bagaimana pengelola BAZ memaknai akuntabilitas dalam pengelolaan zakat, infaq, dan shadaqah (ZIS). Dengan menggunakan metode kualitatif deskriptif dengan pendekatan studi kasus (case study) menemukan bahwa akuntabilitas pengelolaan ZIS pada BAZ Kab. Lumajang didasarkan pada akuntabilitas vertikal dan horizontal. Prinsip yang ditekankan dalam akuntabilitas vertikal adalah prinsip amanah. Sedangkan prinsip yang ditekankan dalam akuntabilitas horizontal adalah prinsip profesional dan transparan.

Terakhir, Kurniawan (2014) melakukan penelitian untuk mengetahui implementasi Good Corporate Governance (GCG) dari aspek akuntabilitas dalam pengelolaan ZIS pada BAZNAS Kab. Jepara. Selain itu, penelitian ini juga bertujuan untuk mengidentifikasi implikasi yang terjadi setelah BAZNAS Kab. Jepara mengimplementasikan (GCG). Hasil penelitian menunjukkan bahwa BAZNAS Kab. Jepara telah mengimplementasikan (GCG) dari aspek akuntabilitas, akan tetapi implementasinya belum dijalankan secara maksimal. Hal ini memberikan implikasi yang positif kepada lembaga dan masyarakat.

\section{Metode Penelitian}

Jenis penelitian adalah penelitian kualitatif dengan pendekatan studi kasus untuk mendeskripsikan dan menganalisis bagaimana organisasi menerapkan akuntabilitas dalam aktivitas organisasi yang meliputi proses dan implikasi yang terjadi. Tahapan penelitian dimulai dengan menentukan topik penelitian, melakukan literatur review, membuat indikator prinsip akuntabilitas, mengumpulkan data penelitian, mengolah data yang telah dikumpulkan, menganalisis hasil penelitian dan menyimpulkan. Penelitian ini menggunakan prinsip akuntabilitas yang dikemukakan oleh Humanitarian Forum Indonesia (HFI) dan Public Interest Research Advocacy Center (PIRAC) yang terdiri dari beberapa indikator. Prinsip dan jumlah indikator tersebut terdiri dari : independensi (2), komitmen organisasi (4), kompetensi (4), non-diskriminasi (2), partisipasi (2), transparansi (3), koordinasi (2), pembelajaran dan perbaikan (2), kemitraan (3), non-proselitis (2), mekanisme umpan balik (3), kemandirian (3) dan keberpihakan terhadap kelompok yang rentan (3).

Penulis mengambil BAZNAS Kab. Agam yang didirikan tahun 2002 dengan nama BAZIS Kab. Agam sebagai objek penelitian. Teknik pengumpulan data yang digunakan adalah wawancara, document review, observasi. Analisis data dilakukan dengan analisis tematik yang merupakan cara mengidentifikasi tema-tema yang terpola dalam suatu fenomena (Boyatzis dalam Putri, 2015). Tema-tema ini diidentifikasi, dikodekan secara induktif (data driven) dari data kualitatif mentah (transkrip wawancara, rekaman dan sebagainya) maupun secara deduktif (theory driven) berdasarkan teori maupun hasil penelitian terdahulu.

\section{Pembahasan}

\section{Sejarah BAZNAS Kabupaten Agam}

Merujuk pada UU RI No. 38 Tahun 1999 tentang pengelola zakat, muncul keseriusan jajaran pemerintah Kabupaten Agam untuk memprakarsai berdirinya Badan Amil Zakat, Infaq dan Shadaqah Kab. Agam (BAZIS Kab. Agam) tahun 2002 dengan dikeluarkan surat keputusan Bupati Agam tanggal 2 Januari 2002. Penamaan BAZIS ini berakhir dengan lahirnya UU No. 23 Tahun 2011 tentang Pengelolaan 
Zakat. Semenjak lahirnya UU ini, maka seluruh BAZIS dan BAZDA yang ada berubah nama menjadi BAZNAS. BAZNAS Provinsi untuk tingkat provinsi dan BAZNAS Kabupaten untuk kabupaten/kota. Undang-undang ini semakin mengukuhkan peran BAZNAS sebagai lembaga yang berwenang melakukan pengelolaan zakat secara nasional. Dalam UU tersebut, BAZNAS dinyatakan sebagai lembaga pemerintah non-struktural yang bersifat mandiri dan bertanggung jawab kepada presiden melalui menteri agama. Dengan demikian, BAZNAS bersama pemerintah bertanggungjawab untuk mengawal pengelolaan zakat yang berasaskan syariat Islam, amanah, kemanfaatan, keadilan, kepastian hukum, terintegrasi dan akuntabilitas.

Untuk menjalankan fungsinya sebagai lembaga pengelolaan zakat, maka BAZNAS Kab. Agam ini pun memiliki visi dan misi tersendiri. Visi yang dimiliki BAZNAS Kab. Agam adalah "Menjadi Badan Amil Zakat Kabupaten Agam yang Amanah, Bertanggungjawab, Transparan dan Profesional." Sedangkan misinya adalah sebagai berikut : (1) Meningkatkan kesadaran umat untuk berzakat melalui BAZNAS Agam. (2) Meningkatkan penghimpunan dan pendayagunaan zakat sesuai dengan ketentuan syariah. (3) Menumbuh-kembangkan pengelola/amil zakat yang amanah, bertanggungjawab, transparan dan profesional. (4) Memaksimalkan peran zakat dalam menanggulangi kemiskinan di Kab. Agam.

Berdasarkan Surat Keputusan Menteri Agama Provinsi Sumatera Barat No. 005 Tahun 2013 Tentang Perpanjangan Jabatan Kepengurusan Badan Amil Zakat Nasional (BAZNAS) Kab. Agam, maka diketahui susunan pengurus terdiri dari : dewan pertimbangan, komisi pengawas, dan badan pelaksana. Sedangkan susunan amil sekretariat terdiri dari bidang-bidang sebagai berikut, yaitu: keuangan, program, administrasi, konter pelayanan mustahik, dan survei yang masing-masing dikepalai oleh seorang ketua yang memiliki beberapa anggota. Masing-masing bidang menjalankan tugas yang telah ditentukan.

Dalam rangka mengoptimalkan kinerjanya sebagai lembaga pengelola zakat, BAZNAS Kab. Agam memiliki beberapa program kerja dalam penyaluran dana zakat kepada masyarakat. Program tersebut terdiri dari Agam Makmur, Agam Cerdas, Agam Sehat, Agam Taqwa, Agam Peduli, dan Zakat Community Development (ZCD).

\section{Analisis Implementasi Akuntabilitas pada BAZNAS Kabupaten Agam}

\section{Independensi}

Dalam PP No. 14 Tahun 2014 Pasal 2 dikatakan bahwa BAZNAS merupakan lembaga pemerintah non-struktural yang bersifat mandiri dan bertanggungjawab kepada presiden melalui menteri. Hal ini terlihat pada program BAZNAS Kab. Agam. Program yang dimiliki oleh organisasi ini mengikuti program yang ditetapkan oleh BAZNAS Pusat. Hanya saja, BAZNAS Kab. Agam memiliki cara tersendiri dalam hal pendistribusiannya. Hal ini mencerminkan adanya kemandirian pada organisasi. Selain itu, kebijakan yang dibuat oleh pemerintah daerah sangat mempengaruhi kinerja. Disini, pemerintah berperan sebagai regulator dan membuat sistem yang memudahkan kerja BAZNAS Kab. Agam. Disamping itu, pemerintah juga berperan sebagai pengawas, pengkritisi dan pihak yang diberikan pertanggungjawaban. Sedangkan terkait keanggotaan dari BAZNAS Kab. Agam, organisasi ini tidak memiliki kebijakan mengenai pelanggaran rangkap jabatan karena di dalam organisasi ini tidak ada pegawai yang memiliki rangkap jabatan. Hal ini tercermin dari struktur organisasi. Semua hal yang dilakukan di dalam organisasi sesuai dengan tanggung jawab masing-masing. Kewajiban yang dimiliki oleh satu orang 
berbeda dengan lainnya. Adanya suatu tugas yang dibantu oleh pegawai lainnya adalah bentuk kerja sama yang ada pada BAZNAS Kab. Agam. Disimpulkan bahwa pada BAZNAS Kab. Agam tidak terdapat kebijakan yang mengatur tentang pelarangan rangkap jabatan. Namun, dalam penerapan prinsip independensi, harusnya BAZNAS Kab. Agam memiliki kebijakan mengenai pelanggaran rangkap jabatan dalam organisasi dan memberikan punishment bagi siapa saja yang melanggar.

UU No. 23 Tahun 2011 menyebutkan bahwa keanggotaan BAZNAS berasal dari unsur masyarakat dan unsur pemerintah. Unsur masyarakat terdiri atas ulama, tenaga profesional dan tokoh masyarakat Islam. Sedangkan dari unsur pemerintah berasal dari kementerian/instansi yang berkaitan dengan pengelolaan zakat. Peraturan ini telah diterapkan oleh BAZNAS Kab. Agam. Selain itu, organisasi ini juga tidak berafiliasi dengan kepentingan politik. Pegawai yang bekerja berasal dari unsur masyarakat dan pemerintah. Namun, tidak termasuk ke dalam kepentingan politik. Walaupun lembaga ini merupakan lembaga yang didirikan melalui pemerintah, namun organisasi ini memiliki cara tersendiri dalam pendistribusian zakat kepada masyarakat. Hal ini telah mencerminkan prinsip independensi yang harusnya ada dalam suatu organisasi.

\section{Analisis Komitmen Organisasi}

Ada beberapa bentuk komitmen yang dilakukan, mulai dari adanya dokumen tertulis dan resmi mengenai visi dan misi organisasi, adanya program kerja dalam respon kemanusiaan serta program strategis dalam proyek, adanya prosedur atau mekanisme (SOP) di dalam lembaga dalam pelaksanaan kegiatan dan adanya kebijakan tentang perlindungan terhadap penerima manfaat. Poin pertama yaitu tentang adanya dokumen tertulis dan resmi mengenai visi dan misi organisasi. Hal ini bisa kita lihat pada web organisasi dan laporan berkala yang telah disiapkan oleh organisasi. Kita juga bisa melihat visi dan misi ini pada web organisasi yaitu www.baznas-kabagam.or.id. BAZNAS Kab. Agam berkomitmen untuk membantu masyarakat yang memang layak dibantu dengan dana yang telah dikumpulkan. Salah satu cara yang ditempuh adalah memperluas media sosialisasi. Ada yang dilakukan dengan media cetak maupun media elektronik. Media ini diharapkan mampu memberikan penjelasan dan gambaran kepada masyarakat mengenai kinerja lembaga. Melalui media cetak, kita bisa lihat pada buletin-buletin yang diterbitkan organisasi, sedangkan media elektronik bisa kita lihat pada web dan sebagainya.

Selanjutnya tentang adanya program kerja dalam respon kemanusiaan serta program strategis dalam proyek. BAZNAS Kab. Agam memiliki berbagai program sebagai upaya penyaluran zakat. Mereka memiliki lima program kerja dalam respon kemanusiaan dan satu program kerjasama dalam organisasi. Lima program tersebut yaitu agam makmur, agam cerdas, agam sehat, agam taqwa dan agam peduli. Sedangkan program kerjasama diberi nama Zakat Community Development (ZCD). Poin selanjutnya yaitu adanya prosedur atau mekanisme (SOP) di dalam lembaga dalam pelaksanaan kegiatan. BAZNAS Kab. Agam mempunyai prosedur atau mekanisme dan program kerja yang jelas. Prosedur kerja BAZNAS Kab. Agam didasarkan pada undang-undang zakat yang berlaku. Menurut data yang diberikan oleh pihak BAZNAS Kab. Agam, mereka memiliki SOP dalam pelaksanaan kegiatan dalam organisasi tersebut. Adapun SOP yang dimiliki oleh BAZNAS Kab. Agam diantaranya adalah SOP pengumpulan dan SOP kepegawaian. Terakhir, adanya 
kebijakan tentang perlindungan terhadap penerima manfaat. Dalam hal ini, BAZNAS Kab. Agam selalu konsisten mengutamakan kepada target yang paling membutuhkan seperti fakir, miskin, bantuan berobat dan bencana alam.

Berdasarkan penjabaran di atas, dalam implementasi prinsip komitmen ini BAZNAS Kab. Agam telah memiliki dokumen tertulis dan resmi mengenai visi dan misi organisasi, melaksanakan tugasnya sesuai dengan prosedur yang dimiliki, mempunyai program-program strategis yang sesuai dengan komitmen organisasi dan adanya perlindungan terhadap mustahik.

\section{Analisis Kompetensi}

Suatu organisasi dikatakan kompeten jika mempunyai tenaga ahli yang mumpuni dan mencukupi. BAZNAS Kab. Agam memiliki dua struktur organisasi. Ada struktur organisasi kepengurusan inti dan susunan amil sekretariat. Namun, staf yang dipekerjakan masih kurang. Hal ini terungkap saat anggota BAZNAS Kab. Agam mengatakan bahwa mereka menghentikan sistem jemput zakat ke tempat muzakki karena menghindari petugas yang bekerja dua kali. Walaupun demikian, tidak menyurutkan semangat BAZNAS Kab. Agam untuk mempunyai tenaga yang profesional ditengah keterbatasan yang dimiliki. Adapun langkah yang ditempuh untuk meningkatkan kinerja dan profesionalitas staf pengelolanya adalah dengan melakukan pembinaan dan pengarahan kepada para stafnya. Selain itu, BAZNAS Kab. Agam juga mengirimkan para stafnya untuk mengikuti pelatihan-pelatihan tentang pengelolaan zakat. Selain peningkatan SDM yang dimiliki, BAZNAS Kab. Agam juga konsisten untuk meningkatkan sistem manajerial dan sistem pelayanan. BAZNAS Kab. Agam mempunyai daya dukung operasional yang baik agar memenuhi standar manajemen, misalnya sistem pencatatan administrasi yang berbasis komputer dan finansial yang mencukupi untuk kegiatan operasional.

Untuk menunjang pelayanan yang baik, BAZNAS Kab. Agam selalu memperhatikan kebutuhan peralatan, sarana maupun prasarana yang diperlukan seperti kendaraan dinas, perlengkapan kantor dan lain sebagainya. Untuk memenuhi kebutuhan yang demikian, BAZNAS Kab. Agam terlebih dahulu menyusun Rencana Kegiatan Aggaran Tahunan (RKAT). Pemerintah Kab. Agam juga sangat mendukung kelangsungan dari BAZNAS Kab. Agam. Hal itu dibuktikan dari bantuan operasional yang diberikan pada BAZNAS Kab. Agam berupa 1 (satu) unit mobil operasional. Selain dalam bentuk bantuan operasional, bentuk lain dari dukungan pemerintah Kab. Agam adalah dengan membuat kebijakan yang mewajibkan PNS untuk membayarkan zakat mereka melalui BAZNAS Kab. Agam. Dukungan dari pemerintah tersebut diharapkan dapat meningkatkan kinerja BAZNAS Kab. Agam. BAZNAS Kab. Agam memiliki prosedur keamanan dan penyelamatan bagi para staf dan relawan di lapangan.

Dari segi kompetensi, BAZNAS Kab. Agam telah melakukan upaya untuk meningkatkan kualitas SDM serta memperhatikan daya dukung operasional melalui sarana dan prasarana yang dibutuhkan. Selain itu, BAZNAS Kab. Agam juga mendapatkan dukungan yang baik dari pemerintah daerah yang diberikan dalam bentuk bantuan operasional. Hal ini bertujuan untuk memberikan daya dukung manajerial kepada BAZNAS Kab. Agam sebagai upaya meningkatkan kinerja lembaga. Namun, akan lebih baik lagi jika BAZNAS Kab. Agam merekrut karyawan baru. Dengan demikian, BAZNAS Kab. Agam bisa menjalankan kembali program jemput zakat ke tempat muzakki sehingga bisa memaksimalkan pengumpulan zakat yang ada pada Kab. Agam. 


\section{Analisis Non-Diskriminasi}

BAZNAS Kab. Agam dalam menentukan target penerima bantuan ZIS terlebih dahulu menghimpun informasi mengenai apakah seseorang tersebut memang benar- benar layak menerima bantuan atau tidak. Salah satu cara yang dilakukan adalah dengan mengadakan survei ke tempat mustahik. Jika mereka memenuhi syarat sebagai penerima bantuan, maka akan memproses lebih lanjut. Sedangkan menyangkut perlakuan terhadap staf, BAZNAS Kab. Agam mempunyai spesifikasi dan persyaratan terhadap rekrutmen pegawainya sehingga staf bekerja secara efektif sesuai dengan bidangnya masing-masing. Jika organisasi memerlukan relawan, semua permohonan yang masuk akan dipanggil. Kemudian akan diuji pemahaman tentang zakat.

Disimpulkan bahwa BAZNAS Kab. Agam dalam prinsip non-diskriminasi telah memperlakukan mustahik dan stafnya sebagaimana mestinya. Tidak ada perlakuan khusus antara satu dengan yang lainnya. Hal ini menunjukkan bahwa BAZNAS Kab. Agam telah menjalankan prinsip non-diskriminasi dalam organisasi. Namun, akan lebih baik lagi jika dalam perekrutan staf, BAZNAS Kab. Agam membuat prosedur perekrutan yang transparan sehingga mencegah terjadinya KKN dan menghasilkan staf yang profesional.

\section{Analisis Partisipasi}

Dalam melaksanakan tugasnya, BAZNAS Kab. Agam telah melibatkan berbagai macam stakeholder internal maupun eksternal. Stakeholder internal diantaranya semua anggora BAZNAS Kab. Agam mulai dari Dewan Pelaksana, Dewan Pertimbangan, Dewan Pengawas dan UPZ. Sementara stakeholder eksternal adalah pemerintah daerah, mustahik, muzakki dan termasuk media yang mempublikasikan.

Dalam hal perencanaan, diketahui bahwa BAZNAS Kab. Agam melakukan rapat dengan mengundang semua anggota terkait untuk pengambilan keputusan. Dalam hal pelaksanaan melibatkan banyak pihak. Pengumpulan dana melibatkan semua golongan baik laki-laki maupun perempuan. Mulai dari perencanaan, pelaksanaan dan evaluasi. BAZNAS Kab. Agam juga memberikan ruang partisipasi kepada publik untuk menyampaikan kritik dan saran melalui kotak saran. Selain itu, masyarakat juga bisa memberikan pertanyaan, kritik dan saran melalui telepon, email maupun facebook atau datang langsung ke BAZNAS Kab. Agam.

Disamping itu, organisasi ini juga berkoordinasi dengan pemangku kepentingan lain. Sehingga dapat diambil kesimpulan bahwa BAZNAS Kab. Agam telah memberikan ruang partisipasi untuk pihak-pihak yang berkepentingan. Hal ini menunjukkan bahwa BAZNAS Kab .Agam telah menerapkan prinsip partisipasi dalam organisasi, namun pelaksanaan partisipasi ini masih bisa ditingkatkan.

\section{Analisis Transparansi}

BAZNAS Kab. Agam membuka informasi yang seluas-luasnya kepada publik mengenai semua hal yang menyangkut pengelolaan dana ZIS. Semua stakeholder bisa mengakses informasi seputar kegiatan yang dilaksanakan oleh BAZNAS Kab. Agam baik dengan mendatangi kantor maupun melalui media. Selain itu juga melayani konsultasi tentang perhitungan zakat bagi masyarakat. BAZNAS Kab. Agam juga melaporkan semua hasil kerjanya dengan membuat laporan pertanggungjawaban yang memuat semua informasi hasil kinerja BAZNAS Kab. Agam. Laporan tersebut disampaikan kepada pemerintah daerah dan BAZNAS 
provinsi. Tidak hanya itu, mereka juga memberikan laporan pertanggungjawabannya kepada menteri secara berkala. Hal ini mencerminkan kepatuhan BAZNAS Kab. Agam terhadap UU No. 23 Tahun 2011 tentang Pengelolaan Zakat.

Laporan tersebut merupakan upaya transparansi yang dilakukan oleh BAZNAS Kab. Agam. Hal ini bertujuan untuk mendorong efektifitas dan efisiensi lembaga serta meningkatkan kepercayaan masyarakat. Selain untuk meningkatkan kepercayaan masyarakat, tujuan lain dari publikasi ini adalah sebagai bahan informasi karena di dalamnya terdapat informasi mengenai pengelolaan zakat. Disimpulkan bahwa penerapan transparansi pada BAZNAS Kab. Agam telah dilakukan dengan cukup baik karena memberikan akses informasi kepada pemerintah dan publik. Namun, sebaiknya BAZNAS Kab. Agam melakukan audit dengan pihak luar (akuntan publik) agar laporan yang diberikan benar-benar terpercaya. Hal ini juga sesuai dengan PP No. 14 Tahun 2014 tentang Pelaksanaan UU No. 23 Tahun 2011 tentang Pengelolaan Zakat.

\section{Analisis Koordinasi}

Dalam melaksanakan tugasnya, BAZNAS Kab. Agam tidak bisa lepas dari kerjasama dengan instansi-instansi lain. BAZNAS Kab. Agam aktif melakukan koordinasi dengan Unit Pengumpul Zakat (UPZ) agar mencapai pengumpulan zakat yang maksimal. Dalam setiap UPZ tersebut ditunjuk tiga orang yang bertanggungjawab terhadap pengumpulan zakat. Selain dengan UPZ yang ada, BAZNAS Kab. Agam juga berkoordinasi dengan pemerintah daerah dan instansi tertentu agar mencapai pengumpulan zakat yang maksimal. Koordinasi yang dilakukan oleh BAZNAS Kab. Agam bersifat rutin. Hal ini sesuai dengan pemaparan responden.

Berdasarkan prinsip koordinasi, BAZNAS Kab. Agam melakukan koordinasi eksternal dan internal. Koordinasi eksternal dilakukan dengan pemerintah sedangkan koordinasi internal dilakukan dengan seluruh organ dan fungsi BAZNAS Kab. Agam, mulai dari staf sampai dengan Unit Pengumpul Zakat (UPZ). Hal ini menunjukkan bahwa BAZNAS Kab. Agam telah menerapkan prinsip koordinasi dalam organisasi.

\section{Analisis Pembelajaran dan Perbaikan}

BAZNAS Kab. Agam melakukan studi banding ke sejumlah Badan Amil Zakat. Studi banding tersebut diharapkan dapat memberikan ide maupun gagasan guna menjadi bahan pembelajaran oleh BAZNAS Kab. Agam. Studi banding yang telah dilakukan diantaranya adalah studi banding ke BAZNAS Dhamasraya, Sijunjung dan Sawahlunto. BAZNAS Kab. Agam juga melakukan perbaikan dengan cara mengevaluasi program yang telah dilaksanakan. Setiap bulan, BAZNAS Kab. Agam melaksanakan rapat pengurus untuk mengevaluasi kinerja yang telah dicapai. Dari evaluasi tersebut diharapkan ada perbaikan yang dilakukan untuk meningkatkan kinerja BAZNAS Kab. Agam. Salah satu cara yang bisa dilakukan untuk memaksimalkan pembelajaran dan perbaikan ini adalah dengan adanya laporan terstruktur dan terjadwal. Laporan ini tidak hanya berisi tentang hal baik saja namun juga kendala yang ditemui di lapangan. Namun, BAZNAS Kab. Agam belum menerapkan hal ini dalam kegiatan organisasi. Hal ini sesuai dengan pemaparan yang diberikan oleh responden pada pembahasan sebelumnya. 
Dengan demikian, berdasarkan prinsip perbaikan dan pembelajaran, BAZNAS Kab. Agam melakukan perbaikan dan pembelajaran melalui pengalaman sendiri maupun belajar dari lembaga lain. Pembelajaran melalui diri sendiri berdasarkan pengalaman lapangan sedangkan pembelajaran dari lembaga lain dilakukan dengan studi banding ke sejumlah BAZNAS. Namun, akan lebih baik lagi jika BAZNAS Kab. Agam memiliki laporan lapangan terstruktur dan terjadwal yang berisi tentang hal baik dan kendala di lapangan. Hal ini akan sangat membantu BAZNAS Kab. Agam untuk lebih baik lagi kedepannya.

\section{Analisis Kemitraan}

BAZNAS Kab. Agam menjalin kerjasama dengan beberapa lembaga. Kerjasama tersebut dalam hal pengumpulan, pendistribusian dan pendayagunaan zakat. Dalam hal pengumpulan zakat, BAZNAS Kab. Agam bekerjasama dengan Satuan Kerja Perangkat Daerah (SKPD)/instansi dan sekolah. Kerjasama ini ditandai dengan dibentuknya Unit Pengumpul Zakat (UPZ) pada instansi tersebut. Selain itu, juga ada dari unsur swasta dan bank syari'ah. Sedangkan dalam hal pendistribusian dan pendayagunaan zakat, BAZNAS Kab. Agam juga bekerja sama dengan berbagai lembaga. Salah satunya dalam hal pendistribusian dan pendayagunaan zakat dalam bidang agam cerdas.

Disimpulkan bahwa BAZNAS Kab. Agam telah melakukan kerjasama dengan berbagai pihak terkait dalam hal pengumpulan, pendistribusian dan pendayagunaan zakat. Hal itu dilakukan demi memaksimalkan dana zakat yang dikumpulkan yang berujung pada kesejahteraan masyarakat. Diharapkan, BAZNAS Kab. Agam dapat memperluas kerjasama mereka dengan pihak lainnya di masa yang akan datang

\section{Analisis Non-Proselitis}

Sebagaimana yang kita ketahui bahwa BAZNAS Kab. Agam merupakan lembaga sosial keagamaan yang pengelolaannya di bawah naungan kementerian agama. Perintah zakat, infak dan shadaqah juga merupakan ketentuan yang diatur oleh agama sehingga pelaksanaannya harus sesuai dengan peraturan agama dan peraturan perundang-undangan. BAZNAS Kab. Agam juga merupakan salah satu lembaga dakwah karena dengan ajaran zakat, infak dan shadaqah dapat mempererat ukhuwah dengan menumbuhkan kepedulian terhadap sesama yang membutuhkan.

Berdasarkan pembahasan sebelumnya diketahui bahwa pendistribusian zakat yang dilakukan oleh BAZNAS Kab. Agam disebar ke semua kecamatan yang ada di Agam. Berdasarkan struktur organisasi, diketahui bahwa BAZNAS Kab. Agam memiliki petugas survei pada setiap kecamatan yang ada di Kab. Agam. Dari hasil survei, petugas organisasi kemudian melakukan sidang untuk membuat keputusan apakah pihak yang disurvei memang berhak dibantu atau tidak. Baik pengurus inti maupun pegawai sekretariat ikut hadir dalam rapat tersebut. Dari hasil rapat tersebut akan diketahui masyarakat yang berhak mendapatkan bantuan dari BAZNAS Kab. Agam. Bantuan yang disalurkan kepada masyarakat bertujuan untuk meringankan beban ekonomi serta menumbuhkan dan memperkuat ukhuwah islamiyah bukan untuk mempengaruhi seseorang agar pindah agama.

Prinsip non-proselitis pada BAZNAS Kab. Agam telah dilaksanakan. BAZNAS Kab. Agam tidak melakukan upaya penyebarluasan keyakinan melalui bantuan yang diberikan. Sesuai dengan Pasal 29 ayat 2 UUD 1945 yang menyebutkan bahwa negara menjamin kemerdekaan tiap-tiap penduduk untuk memeluk agamanya masing-masing dan untuk beribadat menurut agamanya dan 
kepercayaannya itu. Berdasarkan pasal tersebut dijelaskan bahwa setiap warga negara memiliki agama dan kepercayaannya sendiri tanpa ada unsur paksaan dari pihak manapun. Dan tidak ada yang bisa melarang orang untuk memilih agama yang diyakininya. Namun, pada BAZNAS Kab. Agam tidak terdapat pakta perjanjian internal bagi setiap individu yang terlibat dalam kegiatan program. Akan lebih baik jika BAZNAS Kab. Agam memiliki pakta perjanjian tersebut. Hal ini akan menunjukkan bahwa BAZNAS Kab. Agam telah menerapkan prinsip non-proselitis dengan baik.

\section{Analisis Mekanisme Umpan Balik}

Dalam prinsip partisipasi, BAZNAS Kab. Agam sebenarnya telah memberikan ruang bagi masyarakat untuk menyampaikan laporan, pertanyaan, kritik maupun saran. Akan tetapi, hal yang paling penting dalam penerapan prinsip mekanisme umpan balik ini adalah adanya tindak lanjut terkait pelaporan, pertanyaan dan tanggapan tersebut. BAZNAS Kab. Agam menerima laporan dari staf di lapangan dan masyarakat. Laporan dari staf biasanya tentang aktifitas staf di lapangan dalam menjalankan tugasnya. Laporan tersebut pada akhirnya dijadikan sebagai bahan evaluasi dalam rapat yang dilakukan oleh BAZNAS Kab. Agam. Sedangkan laporan dari masyarakat biasanya berkaitan dengan bantuan zakat, infak dan shadaqah (ZIS). Agar mendapatkan bantuan, masyarakat biasanya datang ke kantor BAZNAS Kab. Agam untuk mengajukan permohonan. Namun, ada juga masyarakat yang memberikan laporan atau informasi mengenai adanya target mustahik yang layak diberikan bantuan.

Tindak lanjut dari informasi atau laporan yang diberikan adalah dengan mensurvei target yang dimaksud. Survei ini dimaksudkan untuk membuktikan kebenaran laporan serta untuk menilai apakah target mustahik yang dilaporkan benar- benar layak mendapatkan bantuan atau tidak. Berdasarkan pemaparan di atas, dapat penulis simpulkan bahwa dalam prinsip mekanisme umpan balik, BAZNAS Kab. Agam telah memiliki prosedur dalam menindaklanjuti laporan, baik yang berasal dari staf maupun dari masyarakat.

\section{Analisis Kemandirian}

Dalam prinsip kemandirian, BAZNAS Kab. Agam harus mampu melakukan upaya-upaya mobilisasi sumber daya dan distribusi dana yang tidak menimbulkan ketergantungan. Hal ini terkait dengan penggalangan, pengelolaan dan pendistribusian sumber daya. Secara umum, praktek dari prinsip kemandirian ini adalah tidak bergantung kepada pihak lain. Poin yang ingin disampaikan dalam prinsip ini adalah adanya sumber daya yang jelas dan berkelanjutan baik yang bersifat materi maupun non-materi. BAZNAS Kab. Agam telah memiliki sumber daya yang cukup baik. Sumber daya yang bersifat non-materi misalnya manajemen yang baik dan sistem pengelolaan yang baik, sementara sumber daya yang bersifat materi contohnya staf yang mumpuni, finansial yang mencukupi dan lain sebagainya. BAZN AS Kab. Agam juga bisa mengambil bagian amil sebesar $12.5 \%$ dari dana yang dikumpulkan jika memang diperlukan. Selain itu, organisasi ini melakukan rapat mingguan, bulanan hingga tahunan yang dihadiri oleh pengurus inti dan pegawai sekretariat. Rapat mingguan jika terdapat sesuatu yang perlu dimusyawarahkan antar pengurus sedangkan rapat bulanan dan tahunan membahas mengenai kinerja organisasi dan bagaimana selanjutnya, termasuk disini penentuan program organisasi. 
Sehingga dapat disimpulkan bahwa dari segi kemandirian, BAZNAS Kab. Agam mempunyai sumber daya yang jelas dan berkelanjutan, melibatkan sumber daya dalam pelaksanaan program dan melibatkan pemangku kepentingan dalam penentuan program. Diharapkan, BAZNAS Kab. Agam dapat meningkatkan prinsip ini di dalam organisasi agar bisa lebih baik lagi di masa yang akan datang.

\section{Analisis Keberpihakan Kepada Kelompok Rentan}

Sebagai lembaga pengelola zakat, infak dan shadaqah (ZIS), BAZNAS Kab. Agam jelas mempunyai perhatian khusus pada kelompok maupun individu yang membutuhkan bantuan. Target mustahik yang didasarkan pada delapan golongan sebenarnya sesuai dengan prinsip ini yakni keberpihakan kepada kelompok rentan. BAZNAS Kab. Agam sendiri dalam penerapan prinsip ini membagi ke dalam beberapa program yang bertujuan untuk meningkatkan taraf hidup mustahik, diantaranya:

1. Agam Makmur

Program ini ditujukan untuk membantu kegiatan usaha masyarakat, imaksudkan untuk menunjang ekonomi mustahik. Jika masyarakat Agam membutuhkan tambahan modal dalam usahanya, maka BAZNAS Agam siap membantu dengan mengikuti aturan yang telah ditetapkan. Pendistribusian agam makmur ini dilakukan dengan 3 cara yaitu : (a) Pengembangan usaha dagang (modal untuk usaha). (b) Pengembangan usaha ternak, seperti pemberian sapi, kambing, ayam dan lain sebagainya. (c) Peremajaan alat usaha, seperti pemberian gerobak, becak, perahu dan lain sebagainya.

2. Agam Cerdas

Program ini ditujukan untuk kelangsungan pendidikan/beasiswa kepada pelajar dhu'afa (asnaf fisabilillah/gharimin) yang diberikan kepada pelajar maupun mahasiswa yang ada di Kab. Agam. Hal ini juga sejalan dengan keinginan pemerintah setempat untuk tidak membiarkan adanya anak-anak di Kab. Agam yang putus sekolah. Oleh karena itu, persentase penyaluran zakat dalam program ini pun lebih besar jika dibandingkan dengan program kerja yang lainnya. Pendistribusian agam cerdas ini dilakukan dengan cara : (a) Beasiswa SD - SLTA insedentil. (b) Beasiswa insedentil untuk perguruan tinggi. (c) Beasiswa insedentil untuk masuk perguruan tinggi/SNMPTN/ PMDK baik dalam negeri maupun luar negeri. (d) Untuk pendidikan bagi pelajar yang terancam putus sekolah. (e) Beasiswa binaan BAZNAS Agam (STAIPIQ dan TAMSIS).

3. Agam Sehat

Program ini diadakan untuk menangani masalah kesehatan masyarakat yang ada di Kab. Agam. Adapun pendistribusian agam sehat ini melalui: (a) Biaya berobat dan pendampingan. (b) Pembuatan premi BPJS Kesehatan. (c) Bantuan pembayaran hutang di RSUD. Dan (d) transportasi biaya rujukan.

4. Agam Taqwa

Program ini ditujukan untuk menunjang kegiatan keagamaan dan kemaslahatan umat. Pendistribusiannya dilakukan dengan cara : (a) Pelatihan edukasi dakwah untuk guru TPQ/MDA, imam dan khatib jum'at dan generasi muda madani. (b) Pembinaan muallaf (siswa-siswi muallaf tingkat SLTA dan perguruan tinggi. (c) Operasional da'i daerah pelosok. (d) Syiar kegiatan keagamaan. Dan (e) tebar qurban pelosok nagari.

5. Agam Peduli 
Program ini ditujukan kepada musafir, para fakir, dan hal-hal yang berkaitan dengan bencana alam yang menimpa masyarakat Kab. Agam. Pendistribusian agam peduli dilakukan dengan cara : (a) Konsumtif untuk jompo dan cacat dhu'afa. (b) Tanggap darurat bencana. (c) Bantuan musafir dan gharimin. (d) Bedah rumah mustahik.

6. Zakat Community Development (ZCD)

Program ZCD ini adalah program zakat yang dalam penyalurannya diberikan kepada satu komunitas. Program ini diberikan kepada daerah-daerah yang mayoritas berpenduduk miskin.

Selain itu, organisasi ini memiliki kebijakan tentang perlindungan terhadap penerima manfaat. Hal ini membuktikan bahwa organisasi ini memang melakukan perlindungan terhadap yang membutuhkan. Penentuan pendistribusian dan pendayagunaan tentu mempunyai dasar tersendiri. Namun, yang menjadi kendala bagi adalah organisasi ini tidak mengambil data dari BPS. Dapat disimpulkan bahwa penerapan prinsip keberpihakan kepada kelompok rentan masih memiliki masalah karena tidak adanya data yang pasti mengenai jumlah masyarakat yang harus dibantu oleh BAZNAS Kab. Agam. Sebaiknya, BAZNAS Kab. Agam memiliki data yang bisa dijadikan acuan. Hal ini akan mempermudah dalam menjalankan tugasnya.

Berdasarkan pemaparan terkait implementasi dan analisis akuntabilitas pada BAZNAS Kab. Agam, diketahui bahwa BAZNAS Kab. Agam telah menerapkan prinsip akuntabilitas secara menyeluruh. Hanya saja, penerapan prinsip akuntabilitas ini belum mencapai maksimal sehingga masih bisa ditingkatkan lagi. Diharapkan, BAZNAS Kab. Agam dapat memaksimalkan penerapan prinsip akuntabilitas ini ke depannya.

\section{Kesimpulan}

Dari uraian yang telah dipaparkan sebelumnya, disimpulkan bahwa BAZNAS Kab. Agam telah mengimplementasikan prinsip akuntabilitas dalam organisasi. Namun, ada beberapa hal yang perlu diperbaiki, yaitu : (1) belum adanya kebijakan yang mengatur tentang larangan rangkap jabatan dalam organisasi sejak didirikan. Walaupun demikian, tidak ada pegawai BAZNAS Kab. Agam yang memiliki rangkap jabatan dalam organisasi. (2) Tenaga kerja dalam organisasi kurang memadai. Berdasarkan struktur organisasi, BAZNAS Kab. Agam memiliki pengurus inti dan pegawai sekretariat yang membantu jalannya beberapa fungsi. Namun, pengakuan yang diperoleh dari pegawai bahwa mereka menghentikan satu sistem layanan zakat karena tidak ingin pegawainya bekerja ganda. Hal ini menunjukkan bahwa tenaga kerja dalam organisasi ini sebenarnya kurang memadai. (3) Belum adanya laporan lapangan yang terstruktur dan terjadwal dalam organisasi. Pegawai lapangan hanya membawa berkas yang akan disurvei. Tidak ada laporan lapangan yang terstruktur dan terjadwal yang dimiliki. Jika ada sesuatu yang ditemui di lapangan, hal itu akan disampaikan kepada pegawai lainnya tanpa ada laporan khusus. (4) Belum adanya pakta perjanjian internal bagi setiap individu atau personil yang terlibat dalam kegiatan program. Setiap orang memiliki kebebasan beragama. Hal tersebut juga diatur oleh UU yang ada di negara ini. Oleh karena itu, tidak dibenarkan bagi seseorang untuk mengajak orang lain agar menganut agama mereka. Hal ini juga disadari oleh BAZNAS Kab. Agam. Hanya saja, mereka tidak memiliki pakta perjanjian internal akan hal ini. 
Beberapa hal yang dapat direkomendasi, yaitu BAZNAS Kab. Agam harus membuat kebijakan yang melarang adanya rangkap jabatan pada staf pengelola. Selain itu, juga memberi sanksi pada yang melanggar guna menghindari adanya konflik kepentingan Terkait dengan petugas, sebaiknya merekrut tenaga kerja baru untuk organisasi ini. Hal ini sangat berguna untuk mengoptimalkan pengumpulan zakat pada BAZNAS Kab. Agam. Melalui perekrutan ini, BAZNAS Kab. Agam bisa menjalankan kembali sistem jemput zakat ke tempat muzakki yang dulu sempat terhenti. Pegawai lapangan perlu membuat laporan lapangan yang terstruktur dan terjadwal (tidak hanya hal baik saja tetapi juga kendala di lapangan). Hal ini akan meningkatkan kinerja ke depannya. BAZNAS Kab. Agam perlu membuat perjanjian internal bagi setiap individu atau personil yang terlibat dalam kegiatan program.

Adapun keterbatasan dalam penelitian ini adalah jangka waktu penelitian yang relatif singkat ( \pm 2 bulan) sehingga penulis belum mampu mengeksplor prinsip akuntabilitas secara kompleks pada BAZNAS Kab. Agam. Terbatasnya waktu informan kunci dalam memberikan informasi yang berkaitan dengan topik penelitian sehingga data yang didapatkan dari informan kunci masih terbatas. Masalah aksesibilitas terhadap objek penelitian juga menjadi salah satu kendala yang ditemui selama berada di lapangan. Dan kesibukan kerja yang dihadapi oleh manajemen OPZ menyebabkan penulis tidak bisa mengakses setiap kegiatan yang terkait dengan prinsip akuntabilitas. Hal ini berimplikasi pada belum maksimalnya hasil penelitian dalam mengeksplor lebih jauh kinerja OPZ dalam menerapkan akuntabilitas organisasi.

Penelitian mengenai akuntabilitas organisasi non profit khususnya di bidang zakat tidak hanya sampai di sini. Kedepannya diharapkan adanya penelitian di bidang zakat dengan pemilihan objek yang berbeda, waktu yang lebih lama dan pembahasan yang lebih dalam mengenai isu-isu akuntabilitas yang dirasa perlu dikembangkan demi kepentingan akademis dan praktik.

\section{REFERENSI}

Al-Qur'an terjemahan

Asahi, Suciana, Gusti. 2014. Memahami Akuntabilitas Organisasi Pengelola Zakat: Studi Kasus Pada Badan Amil Zakat Nasional (Baznas) Kota Padang Dan Lembaga Kemanusiaan Nasional Pkpu Cabang Padang. Politeknik Negeri Padang

Endahwati, Yosi, Dian. 2014. Akuntabilitas Pengelolaan Zakat, Infaq dan Shadaqah (ZIS). Jurnal Ilmiah Akuntansi dan Humanika JINAH Vol. 4 No. 1 Singaraja

Ihsan, Hidayatul dan Gustina. 2008. Manajemen dan Akuntabilitas Institusi Pengelola Zakat: Suatu Tinjauan Teoritis. Jurnal Akuntansi dan Manajemen Vol. 3 No. 1, hlm. 17-24

Khaerany, Rizky. Habbe, Abdul, Hamid dan Rasyid, Syarifuddin. 2013. Akuntabilitas dan Transparansi Lembaga Pengelola Zakat dan Pengaruhnya terhadap Kualitas Lembaga Amil Zakat (Pandangan Muzzaki dan Amil Zakat). Universitas Hassanudin

Kurniawan, Ahmad. 2014. Analisis Implementasi Good Corporate Governance dari Aspek Akuntabilitas pada Badan Amil Zakat (Studi Kasus pada BAZNAS Kabupaten Jepara). UIN Walisongo Semarang

LAN dan BPKP. 2000. Akuntabilitas dan Good Governance. Jakarta

Mardiasmo. 2009. Akuntansi Sektor Publik. Yogyakarta. 
Mukti, Ali. 2015. Studi Analisis Penyaluran Zakat Melalui Program Kampung Berkah Mandiri Di LAZNAS Baitul Maal Hidayatullah Cabang Kudus

Nikmatuniayah. 2012. Akuntabilitas Laporan Keuangan Organisasi Pengelola Zakat Yayasan Daruttaqwa Semarang

PIRAC \& HFI. 2011. Pedoman Akuntabilitas Pengelolaan Bantuan Kemanusiaan di Indonesia. Depok

Putri, Silvia, Eka. 2015. Implementasi Good Governance Pada Organisasi Pengelola Zakat : Studi Kasus Pada Badan Amil Zakat Nasional (Baznas) Kota Padang. Politeknik Negeri Padang

Peraturan Daerah Kabupaten Agam Nomor 14 Tahun 2007 tentang Pengelolaan Zakat

Peraturan Pemerintah Nomor 14 Tahun 2014 tentang Pengelolaan Zakat

Pernyataan Standar Akuntansi Keuangan Nomor 109

Undang-Undang Republik Indonesia Nomor 23 Tahun 2011 tentang Pengelolaan Zakat

Wahab, Norazlina Abd, dan Abdul Rahim. 2011. A Framework to Analyze Efficiency and Governance of Zakat Institutions. Universitas Utara Malaysia 